\title{
(Dys-)Functionalities of corruption: comparative perspectives and methodological pluralism
}

\author{
Tobias Debiel • Andrea Gawrich
}

\begin{abstract}
Corruption is usually understood as hampering political development, economic growth and democratic participation of citizens, but comparing the effects of corruption for different political regimes presents astonishingly complex findings. The ongoing persistence of corruption underlines that it is not only dysfunctional, but can be highly functional as well. This special issue brings together contributions from comparative politics, political science and economics which precisely focus on these (dys-)functionalities of corruption in political regimes across various world regions. The question of methodological pluralism is especially important for studying corruption comparatively. While on an international level a trend towards an increased use of quantitative methods in political science as well as in economics can be observed, the special issue underlines the importance of having a pluralistic approach for grasping the complex and multi-layered effects of the phenomenon. Of similar importance is the adoption of a comparative perspective that includes different world regions in order to understand the different roles of corruption in developing, transforming and developed countries alike. This editorial summarises the key findings of the special issue and sheds light onto the overarching questions, desiderata, and avenues for further research on corruption that link the various methodological, conceptual, and empirical studies in this issue.
\end{abstract}

Keywords: Corruption $\cdot$ Methodological pluralism $\cdot$ Comparative politics

\section{(Dys-)Funktionalitäten von Korruption: Vergleichende Perspektiven und methodologischer Pluralismus}

Zusammenfassung: Korruption wird gemeinhin als Hemmnis für politische Entwicklung, wirtschaftliches Wachstum und eine demokratische Willensbildung verstanden, aber eine vergleichende Perspektive auf die Effekte von Korruption für unterschiedliche politische Regime kann erstaunlich komplexe Ergebnisse hervorbringen. Die anhaltende Beständigkeit von Korrup-

Published online: 20.11 .2013

(C) Springer Fachmedien Wiesbaden 2013

Prof. Dr. T. Debiel $(\bowtie)$

Institute for Development and Peace (INEF),

Käte Hamburger Kolleg/Centre for Global Cooperation Research, University of Duisburg-Essen, 47048 Duisburg, Germany

e-mail: tobias.debiel@inef.uni-due.de

Prof. Dr. A. Gawrich

Institute for Political Science, Justus-Liebig-University Gießen,

Karl-Glöckner-Str. 21 E, 35394 Gießen, Germany

e-mail: andrea.gawrich@sowi.uni-giessen.de 
tion unterstreicht dabei, dass das Phänomen nicht ausschließlich hemmende Auswirkungen hat, sondern dass es vielmehr auch sehr funktionale Effekte hervorbringen kann. Das vorliegende Sonderheft versammelt Beiträge aus der Vergleichenden Regierungsforschung, Politikwissenschaft und Wirtschaftswissenschaft, die genau diese (Dys-)Funktionalitäten in politischen Systemen aus unterschiedlichen Weltregionen in den Mittelpunkt ihrer Untersuchungen rücken. Von zentraler Bedeutung für eine vergleichende Korruptionsforschung ist dabei ein pluralistisches Methodenverständnis. Obgleich international in der Politikwissenschaft wie den Wirtschaftswissenschaften quantitative Zugänge verstärkt herangezogen werden, betont das Sonderheft die Bedeutung eines pluralistischen methodischen Zuganges, um die komplexen und vielschichtigen Effekte von Korruption erfassen zu können. Gleichfalls bedeutsam ist eine vergleichende Perspektive, die verschiedene Weltregionen einbezieht, um die unterschiedlichen Funktionen für sich entwickelnde Länder, Transformationsländer und industrialisierte Länder angemessen beleuchten zu können. Das Editorial zum Sonderheft fasst die zentralen Ergebnisse der Beiträge zusammen und beleuchtet die übergreifenden Problemstellungen, Desiderata und Möglichkeiten für die zukünftige Korruptionsforschung, die die unterschiedlichen methodischen, konzeptionellen und empirischen Studien des Sonderhefts verbinden.

Schlüsselwörter: Korruption · Methodologischer Pluralismus · Vergleichende Politikwissenschaft

Research into corruption, particularly in the context of political and economic transformation, has experienced an enormous upturn. One significant catalyst for this, as Bader et al. highlight in this special issue, is the increasing availability of aggregated data from the second half of the 1990s onwards, with which it has been possible to measure the phenomenon of corruption indirectly. This volume reflects the most recent debates and insights in political sciences and presents articles which, with varying methodological approaches, investigate the functionality and dysfunctionality of corruption in industrial nations, in societies undergoing transformation, and in developing countries. For this purpose, this special issue provides conceptual analyses as well as single and comparative case studies and quantitative research.

Section A of this special edition places the focus on conceptual issues, takes a closer look at methodological pluralism in corruption research, and raises issues of definition (Johnston 2005a) that will be taken up in various of the following articles. On the one hand, there is the definition provided by Transparency International, which by now is widespread and commonly used, according to which corruption is understood as "the abuse of entrusted power for private gain". However, the phenomenon is a multi-layered one, and may be interpreted differently in varying cultural and political contexts.

Section B investigates, based on case studies, to what degree corruption plays a functional or dysfunctional role and why systemic corruption remains stubbornly persistent even through processes of political and economic transformation. The section provides comparisons from Latin America, Sub-Saharan Africa and Asia, as well as a case study on the People's Republic of China.

Recent research increasingly concentrates on the effects which corruption has on the attitudes of citizens and their satisfaction with the political system, both in democracies and in transforming societies. It is precisely this aspect that is stressed in Section C, which significantly draws on surveys. The nexus of democracy and legitimacy on the one hand 
and the justification of corrupt practices on the other hand are investigated with regard to the European democracies as well as the democratic and hybrid regimes in the Americas.

Research on corruption is, even if the papers are predominantly empirical and analytical, often implicitly and sometimes also explicitly normative. The focus often lies on the potentially dysfunctional effects of corruption for economic growth, well-balanced social development, political transformations, good governance or trust held by citizens in democratic and rule of law institutions (e.g. Priddat and Schmid 2011). As a consequence it is not surprising that anti-corruption policies are of primary interest not only for political evaluations, but also for academic studies. Nevertheless, this comparatively young branch of research is particularly hampered by the fact that there are remarkably few examples of successful anti-corruption policies. This is even more the case since international donors, with significant involvement of the World Bank, have strongly brought this point into focus within the framework of governance promotion (Debiel and Pech 2011).

Finally, section D aims on the basis of two comparative case studies of young democracies in Eastern Europe and East Asia at ascertaining factors of success and failure for such kinds of reform policies. With respect to the global development of norms, it is additionally investigated how the focus of the debate has shifted from "bad business" to "bad government".

This special issue is first and foremost interested in investigating the role of corruption for different types of political systems. It therefore focuses both on established or young democracies and on transforming or autocratic regimes. Besides the potential dysfunctional effects, a look is also taken at potential functional effects during selected phases of societal development (see for democratization processes the overview in Pech 2009). For example, corruption might also have stabilising effects on political governance, and might in phases of economic upheaval fill a vacuum left by the failings of formal institutions. At the same time, there is a relatively broad consensus that these functional effects bear the risk that corruption becomes systematic or endemic, due to the self-reinforcing factors, which corrupt practices bear. Corruption, then, is a barrier to the efficient allocation of resources as well as a heavy burden for the accountability and legitimacy of governance (e.g. Funderburk 2012). Several contributions in this special issue offer a deeper understanding why corruption can be remarkably persistent and resistant against domestic as well as external anti-corruption policies in many cases. It is furthermore explained why citizens might regard engaging in corruptive interactions as appropriate and legitimate behaviour.

Now what are the central insights of the articles gathered in this special issue? Is there an analytical nexus between the results of the different studies? Is there a consensus on consolidated states of research? Where are new paths for future studies recommended? In the following, we summarize some results of this volume with regard to these questions.

The first contribution of this special issue by Florian Bader, Patric von Maravić, B. Guy Peters and Michael Tauch gives attention to Methodological Pluralism in Corruption Research. The paper aims to shed light on a topic that has so far achieved only scant attention: how do researchers acquire knowledge on the phenomenon of corruption? Does corruption research in economics and in political science meet the requirements of methodological pluralism and thus can high validity be claimed for its findings? Bader et al. try to answer these questions by carrying out a content analysis which includes a random 
selection of empirical articles in the fields of economics and political science. The selected articles were published in SSCI journals between 1990 and 2010 (the first one in 1996). Some findings can be highlighted as follows: firstly, the availability of aggregated data, such as that of Transparency International, seems to have brought about a clear increase in the number of articles after the year 2000. Secondly, from 2004 onwards a raising number of quantitative studies can be observed. There is a dominance within the field of economics, whereas in the field of political sciences the use of quantitative and qualitative methods is still balanced overall. It may also be noted that the use of quantitative methods is particularly significant within the USA. Thirdly, research based on indices such as the Corruption Perception Index (CPI) as a data source dominates, followed by surveys and then, some way behind, by document analysis and experiments. Mixed-method approaches, which have great advantages in terms of validity, were rarely present, in only $14 \%$ of the articles. In the context of this "constrained pluralism", the authors finally voice support for the triangulation of empirical evidence, since the indirect measurement of corruption very clearly only displays the phenomenon partially. The prerequisite for this kind of approach is an acceptance of different "ways of knowing" — an attitude which this special issue also adheres to.

In his article, Wolfgang Muno picks up on the tense relationship between morally postulated and socially appropriate norms although corruption is often considered to be a detrimental phenomenon for political, economic and social development, in numerous countries it is not a deviant form of behaviour from a social point of view, but one which is entirely in accordance with the respective expectations. According to Muno, this tense relationship can be captured best by understanding corruption as an informal institution, and political clientelism as the central variety of corruption. In this way, the social embeddedness of corrupt practices becomes analytically relevant, instead of the isolated consideration of dyadic interactions. Based on a taxonomy which distinguishes between the most varied forms of corruption, Muno determines five properties of clientelism: dyadic network, asymmetrical, personal and enduring, reciprocal and voluntary. Building on this, he clarifies with reference to selected studies what the advantages and disadvantages of the most varied methods of data collection are. Muno takes a critical view towards the widespread use of proxies, which in his view causes considerable problems relating to validity and reality. With reference to a seminal study by Brusco et al. (2004) on "Vote Buying in Argentina", he clarifies the advantages of independent empirical data collection. At the same time, this is admittedly often limited to individual cases in view of its correspondingly high costs. Thus, expert surveys could gain significance as a pragmatic and cost-conscious "second-best option". In order to understand the underlying mechanisms leading to clientelism, Muno moreover recommends ethnographic studies. Overall, in the same way as Bader et al. do, Muno expresses support for methodological pluralism and a stronger use of methodological triangulation.

In our section B on Political Rule, Governance and Growth, the debate on corruption and governance (e.g. Rose-Ackerman 1999) and corruption and growth (e.g. Sindzingre and Milelli 2010) is taken up with specific foci. Christian von Soest analyses persistent systemic corruption and tries to explain "why persistent systemic corruption and economic liberalization have failed to undo an old evil". He provides a qualitative comparative analysis. His small-N comparison includes five countries from three regions: These 
are the presidential systems Argentina, Indonesia, the Philippines, Kenya, and Zambia, which have all experienced political and economic liberalisation. Furthermore, Venezuela is added as a contrasting case which is characterised by regressive tendencies after Hugo Chavéz' election as President in December 1998. Von Soest stresses core assumptions that prevail in the theory-guided debate, based on a review of literature: "Theoretically, both democratisation and economic liberalisation can reduce corruption on their own, yet the repercussions are likely to be strongest when they go together." He conceptualises "systemic corruption as an expression of personalised politics". Together with clientelism and the informal concentration of power, corruption characterises neopatrimonial rule.

After a careful case-by-case analysis, von Soest points out the fact that corruption is part of the nonlinearity of democratization in the respective countries. The paper finds that systemic corruption persists despite the fact that the informal concentration of power has been reduced through political transition processes. The extent of corruption, clientelism and power concentration, the paper finds, is mainly influenced by the level of democratisation. Democratic transition processes, however, have not led to substantial constitutional checks and balances of executive power. Furthermore, and contrary to selected large-N research, von Soest's analysis of case studies is unable to prove the hypothesis that the 'endurance of democracy' (measured by the number of years a democracy has been existing) has an impact on the level of corruption. Finally, neither economic liberalisation nor the per capita income seem to clearly impact on the level of systemic corruption. The paper thus concludes that personal rule and in particular the level of democratisation should be underlined as the main explanatory factors for the persistence or absence of corruption.

In his contribution on relational corruption in the PR China, Markus Taube provides an in-depth understanding of the functionalities and dysfunctionalities of corruption for economic development. Like Muno, Taube relies on an institutionalist framework and in particular focuses on the Chinese guanxi networks. The puzzle of the paper is as follows: why has China been able to achieve two-digit growth rates over the past three decades, while corrupt practices have become a crucial feature of day-to-day life? As a starting point, Taube holds that "(c)orruptive transactions, just like all other economically-based interactions, are grounded on the exchange of specific bundles of property rights" and that respective payments accordingly can be interpreted as "a form of investment". The guanxi networks, in this conceptual reasoning, provide a club framework for transactional security in a context where formal institutions are deficient and entrepreneurs look for environments in which their political risks can be mediated. Networks that allow for these transactions, therefore, can temporarily have a positive impact on the efficiency of allocation of resources, something which Taube, among other examples, illustrates with reference to the management of international liquidity.

However, this functionality is put into question as soon as the legal system adjusts to economic transformation and network discipline conflicts with law-abiding behaviour as a reasonable alternative. In such a context, corruption may, if it transcends a certain threshold, become self-reinforcing and increasingly antagonistic to formal norms. To express Taube's findings in a nutshell: corruption in the early stages of transformation might partly contribute to overcoming the problems of a hybrid system of order and also to appeasing bureaucratic and party cadres with regard to emerging entrepreneurs by 
giving them access to political rents. However, as corruption transforms its quality from 'entrepreneurial' towards 'predatory', the institution becomes increasingly dysfunctional with respect to economic growth and the efficient allocation of resources.

In our section C, which is on Corruption and Citizens' Attitudes, Ina Kubbe's article focuses on the interplay between corruption and trust, both interpersonal and institutional, in established European democracies. It is apparent first of all that, although some democracies in Scandinavia and Western Europe are assumed to have a very low level of corruption, the rest of the picture is rather varied with respect to Western and post-communist democracies. Kubbe interprets trust as being an important part of social capital, which is normatively opposed to the institution of corruption. Correspondingly, a large part of the literature argues that the two phenomena have a negative correlation. A lack of trust in institutions in turn, one can assume, tends to go hand-in-hand with non-observance of laws. According to Kubbe, however, one unresolved issue is the relationship between "interpersonal trust, which means trust in other members of society, and institutional trust, which means trust in political institutions, such as the government and political parties". Hence institutional trust is not necessarily translated into interpersonal trust - and vice versa. In order to explain this only limited determinacy, Kubbe develops a model which conceptualises political corruption as a mediating variable, and tests it with data from Transparency International (for the measurement of corruption) and the European Social Survey (ESS, for interpersonal and institutional trust) for 24 countries. The level of democracy and the legacies of the communist past are used as control variables. Her results indicate firstly that high levels of corruption negatively influence civic trust as well as people's trust in political institutions. Secondly, low degrees of interpersonal trust cause higher levels of corruption which, in turn, reduce institutional trust - an effect that is stronger in Central and Eastern European Countries than in Western democracies. The conclusions drawn from this are highly politically relevant: hence with a low degree of corruption the trust in political institutions can be increased when the citizens' perception increases that they can rely on each other in their mutual expectations. If there is comparably high corruption, according to Kubbe, good governance and efficient action on the part of the government are in turn good prerequisites to increase the legitimacy of political institutions.

In a similar vein to Ina Kubbe's study, the article of Daniel Stockemer and Aksel Sundström investigates the nexus between the satisfaction of citizens with their democracy and the extent of corruption. The two authors draw a connection between two strands of the literature which have been only partly combined until now: the debate on the (dys-) functional influence of corruption on economic growth, political participation and effective governmental action on the one hand, and on the other hand the discussion on the satisfaction of citizens in democracies with the concrete performances of the political system. At the interface of the two strands of research, Stockemer/Sundström see clearly convincing empirical evidence that there is a negative correlation between corruption and satisfaction with the democratic system. However, there has been little investigation of "the relative influence of corruption on citizens' satisfaction with democracy with regard to other factors such as economic performance, constitutional mechanisms and policy representation of citizens". Moreover, both authors state that the independent variable is mostly conceived in a very general manner. Accordingly, little is known about the effects of different types of corruption on citizens' attitudes. 
This is precisely what constitutes the article's key research question, which is: "Is it petty or grand corruption that influences citizens' satisfaction with democracy?" Stockemer/Sundström understand the former as being "small-scale corruption among public servants during the implementation of policy", while the latter refers to "large-scale corruption involving decision-makers during the formulation of policy". In a similar way to Kubbe, they use a sample of European democracies, here 26 in number. The dependent variable is measured with the help of data from the European Social Survey (ESS). For the independent variable, small-scale corruption in the areas of police and the justice system is also captured with ESS data, but corruption on the macro level with the World Bank Control of Corruption Indicator. In order to capture the relative weight of individual perceptions of corruption in relation to other factors, gender, age, education and income are recorded on the micro level as control variables. On the macro level, there is a control of variables for development, economic growth, democratic stock (understood as endurance of democracy) and income inequalities. As well as bivariate relationships, Stockemer/Sundström use multi-level modelling which is capable of clustering individual data in national contexts. As a result, both on the micro level and macro level negative correlations can be found between the independent variables used and the satisfaction of citizens. The result of the Hierarchical Linear Model (HLM) is particularly interesting: it shows that perceptions on the micro level have a more decisive influence in comparison with those on the macro level, and that negative perception of judges has a particularly disadvantageous effect on satisfaction with democracy. As expected, individuals' opinions of the performance of the government and economic performance also have an influence. Furthermore, satisfaction rises with a higher level of education. The control variables on the macro level, by contrast, are much less relevant. Stockemer/Sundström accordingly suggest that future research should deal in even more depth with the question of the sectors in which corruption has a particularly devastating effect on the satisfaction of the population.

Stockemer/Sundström recommend precisely what Simone Bohn does in the subsequent article: including democracies outside of Europe in further research. In her article on "rational-choice corruptors" twenty-five countries of the Americas are analysed. On the one hand she evaluates survey data from the AmericasBarometer 2010 and on the other hand she uses country-level statistics, in particular the World Bank's Ease of Business Index, the Fraser Institute's Economic Freedom Index, the Economist Intelligent Unit's (EIU) Democracy Index and the 'Judicial Independence' indicator of the World Economic Forum, as well as the Freedom House Democracy Score. Her research question concentrates on individual citizens, who are not conceptualised as pure victims of the system, but whose agency options are also taken seriously. Her core research question therefore aims to find out under which circumstances citizens become "rational choice corruptors" (RCCs) and regard it as justified to take part in corrupt transactions. Building on relevant literature, Simone Bohn investigates three potential factors of influence: excessive bureaucracy, perception of rampant corruption among public sector employees, and low risk of detection and punishment. The latter can also be recorded in terms of the functioning of the judicial and democratic systems and, furthermore, provides a link to the hypotheses of Stockemer/Sundström, who emphasise the high importance of the effectiveness of the judicial system for citizen's behaviour. 
On the basis of multilevel-effects logistic regressions, Bohn comes to the conclusion that excessively strong state regulation cannot be used as a basis to predict whether participating in corrupt practices is regarded as legitimate or not. Moreover, the general level of democracy seems to have only low significance for "rational choice corruptors". The judicial independence leads to slight but not significant effects. In contrast, individual variables have a stronger influence. Hence, the probability of being a rational choice corruptor is evidently higher for men than for women and the tendency to justify participating in corrupt practices decreases with age. However, the most important result of the study is that RCCs are more exposed to experiences of corruption than other citizens. It is particularly noticeable that "citizens who contact the local government to obtain stateregulated goods and services have a $30 \%$ higher odds ratio of justifying the occasional use of bribes than those who are not in touch with the municipal actors". Moreover, the perception of widespread corruption has a negative effect on the attitude of citizens with respect to the illegitimacy of corruption. In contrast, the feeling that the government is proactively fighting corruption has a positive effect on this attitude. To sum up, Bohn, in a similar way to Stockemer/Sundström, emphasises the relevance of micro level assessments compared with macro-societal variables.

These studies indicate that the effectiveness and incorruptibility of the judicial system could offer a point of leverage with regard to satisfaction with democracy and the delegitimisation of corrupt practices. Such issues, among others, are dealt with in the final section (D), which is on Policies and Norms of Anti-Corruption. Particular attention is paid to young democracies. Nicole Gallina begins with a comparative investigation of anti-corruption policies in the Czech Republic and Slovakia. The focus is on the degree to which the political elites of both countries have incorporated anti-corruption measures in their policies, and what effects they have, with respect to the different influencing factors and forms of corruption. The article explicitly adopts an actor-centred perspective. Gallina elaborates that the corruption issue has been highly politicised in both countries and that particular opportunities for political elites open up when there is a politically dependent judiciary and a fragmented political space. She convincingly argues that efforts to fill controlling institutions with politically loyal personnel represent a central obstacle for the successful implementation of anti-corruption measures. The electoral accountability which could bring about some resistance here is countered by the fact that oppositional elites often give up their anti-corruption rhetoric when they get into power.

On the basis of expert interviews and the evaluation of studies and media reports, Gallina creates a "thick description" of the Czech Republic for the most diverse periods of government about how attempts to institutionalise anti-corruption policies were stopped and failed due to virtually mafia-like circumstances. In Slovakia, for some time under the Prime Minister Mikuláš Dzurinda (1998-2006) there were more serious efforts to implement both preventive and repressive measures, but these were either largely reversed or stopped under the following government of Robert Fico. In her conclusions, Gallina points out the high significance of selected actors in the fight against corruption, particularly the Prime Minister and the Ministers of the Interior and of Justice. She also emphasises that the staffing of police, state prosecutors, anti-corruption authorities and the appropriate courts by meritocratic criteria is a crucial prerequisite for successful policies on corruption. 
Christian Göbel carries out a structured, focused comparison of anti-corruption in Taiwan and South Korea - two East Asian countries which show similar conditions with regard to their geography and their level of economic development as well as the type of regime and regime change. He is primarily interested in the circumstances under which corruption can be reduced: are gradual approaches more promising? Or do reforms have better chances of success when they are attempted in times of radical change? Precisely such situations were present in Korea in 1993 when Kim Young-sam, the first civil president, came to power and in Taiwan in the year 2000 when the Kuomintiang (KMT), which had been the sole rulers up to then, was displaced by the Democratic Progressive Party (DPP). In order to capture this phase, Göbel deploys the 'critical juncture' approach which is embedded in a historical institutionalist perspective. It is assumed that existing institutions continue to survive even if they have a high degree of functional inefficiency due to the high costs of change. However, radical changes are possible in crises and situations of upheaval. Drawing on arguments from institutional economics, he argues that anti-corruption policies involve replacing "relational contracts" with "legal contracts" and hence that the transformation of corrupt practices can be conceptualised as a "collective action problem".

His two case studies show that the change of governments made possible by democratisation offered political leaders in both countries particular freedom of action. During these critical junctures, however, noteworthy differences occurred between Korea and Taiwan: In South Korea the politicians who had previously been in the opposition gained the opportunity, alongside the introduction of anti-corruption measures, to simultaneously take over a part of the clientelist networks of their predecessors. Accordingly there were only half-hearted efforts against corruption. In Taiwan, on the other hand, the corruption networks were so closely connected with the former governing party, KMT, that they were not accessible for the DDP. There was hence no alternative to pursuing a policy of implementing the promises made in their electoral campaign. It can thus, rather counter-intuitively, be concluded that anti-corruption policies are pursued all the more emphatically by new political elites the more strongly deeply rooted networks existed and were linked with the former elites in a way that made them hardly accessible to new power-holders.

The final article of the section turns to the changing global norm of anti-corruption and related policies. Anja P. Jakobi illustrates how the anti-corruption norm has become internationally accepted within three-and-a-half decades and has brought about new forms of transnational governance in which the most varied groups of actors are involved. This development came in three waves: following the US which first became active with a clear focus on business bribery, the 1990s saw broad international support for the cause. In this second wave more fundamental moral questions were also dealt with. With the beginning of the new millennium, a third wave of combatting corruption led to bad governance being understood as a central constituent of the problem.

The article also points to the fact that the high acceptance of the norm, the broadening of its contents and the introduction of corresponding mechanisms and institutions do not necessarily lead to its implementation. According to Jakobi, this can be seen in the fact that Bulgaria and Greece belong to the 16 countries which have ratified four or even more conventions in this area - and yet they constantly suffer from a high level of corruption. 
At the same time, the author also maintains that we still very much rely on perceptions when we try to capture what the degree of corruption is in individual countries and how this changes over time. Thus, empirical findings on the extent and trends of corruption even in advanced research have to be treated with caution. The new corruption indices and rankings, as Michael Johnston (2005b, p. 866) stated, are not wrong: "Rather, it is to emphasize the continuing need for a richly comparative and historical view of corruption built upon diverse kinds of evidence and theory".

As the short presentation above shows, the articles in this special issue reflect the remarkable dynamics which currently characterise the research on corruption. Despite the fact that there is an international tendency towards a more homogeneous use of quantitative methods in economics, approaches from political science still provide a rich variety of methods - alongside the increasing tendency to critically reflect on data sources and methods. This is all the more the case if research outside of North America is considered, in which qualitative approaches, including single and comparative case studies, continue to be highly significant. In this special issue it has become particularly evident that the persistence of corruption, as well as the discrepancy between norms and expected social behaviour, can be captured fruitfully with institutional economic approaches (see e.g. Lambsdorff 2007). Particular attention has also been paid to the multi-layered nexus of personal und institutional trust, corruption and democratic legitimacy. This has not only to do with the loyalty of citizens towards their state, but also with the circumstances under which citizens justify their participation in corrupt practices. In addition, the examples of young democracies in Eastern and Central Europe and East Asia have made it clear that the rapid spread of the anti-corruption norm on a global level, as well as its change in content, has continued to meet with stubborn resistance against implementing this norm on a national level. The case studies within this special issue suggest that fundamental reforms only have good odds of succeeding if there is a 'critical juncture' in a country's political development and if such policies fit with the calculations of the ruling political elites.

This special issue, despite the wide range of articles it presents, was of course only able to pick up on some of the many relevant issues in present-day (anti)corruption research. For instance, even if the diverse definitions of corruption and their embeddedness in social and institutional contexts have been discussed, the varying understandings of corruption in different cultural and semantic contexts could only be reflected very partially. Further research in this field could e.g. contribute to inter-regional cultural perceptions, especially of systemic elements of corruption. With respect to the global norm of anti-corruption, to take a further example, it was only possible to do partial justice to the performative effects that respective speech-acts have in the asymmetric field of development cooperation. We must also concede that the empirical insights do not represent the different regions of the world equally. For example, there is much more to learn about corrupt practices e.g. in failed states or post-conflict societies than this publication can offer. Last but not least, despite the fact that this publication reflects various methodological approaches, experimental research designs do not play a role in this special issue (see e.g. Lambsdorff and Frank 2010). Nonetheless the editors are confident that this special issue, with its variety of analytical perspectives and empirical approaches, not only provides fascinating insights into research on corruption, but also fosters systematic research on the issues and topics which it covers. We hope that future comparative research which is open for meth- 
odological pluralism will gain a certain stimulus not only for (anti-)corruption research but also for the role of informal practices, informal ruling and informal institutions in political systems at a broader analytical and empirical level.

At the end of our editorial, we would like to thank all who have contributed to making this special issue possible. Besides the authors and anonymous reviewers, we especially want to thank Holger Niemann, researcher at the Institute for Development and Peace (INEF), for his valuable collaboration in the editing and coordination of this publication. Our thanks also go to the main research area "Transformation of Contemporary Societies" of the University of Duisburg-Essen, which kindly promoted and supported the development and realisation of this publication project.

\section{References}

Brusco, Valeria, Marcelo Nazareno, and Susan Stokes. 2004. Vote buying in Argentina. Latin American Research Review 39 (2): 66-88.

Debiel, Tobias, and Birgit Pech. 2011. Corruption as an obstacle to development? Taking Stock of research findings and the effectiveness of policy strategies. In UNIKATE 40 "Social Sciences - Comparative, International, Transnational”, 16-25. Essen: University of Duisburg-Essen.

Funderburk, Charles, ed. 2012. Political Corruption in Comparative Perspective. Sources, Status and Prospects. Farnham: Ashgate Publishing.

Johnston, Michael. 2005a. Keeping the Answer, Changing the Questions: Corruption Definitions Revisited. In Dimensionen politischer Korruption. Beiträge zum Stand der internationalen Forschung, ed. Ulrich von Alemann, 61-76. Wiesbaden: VS Verlag für Sozialwissenschaften.

Johnston, Michael. 2005b. Measuring the new corruption rankings: Implications for analysis and reform. In Political Corruption. Concepts \& Contexts. 3rd Ed., eds. Arnold J. Heidenheimer and Michael Johnston, 865-884. New Brunswick/London: Transaction Publishers.

Lambsdorff, Johann Graf, and Björn Frank. 2010. Bribing versus gift-giving - An experiment. Journal of Economic Psychology 31 (3): 347-357.

Lambsdorff, Johann Graf. 2007. The Institutional Economics of Corruption and Reform: Theory, Evidence, and Policy. Cambridge: Cambridge University Press.

Pech, Birgit. 2009. Korruption und Demokratisierung. Rekonstruktion des Forschungsstandes an den Schnittstellen zu Institutionenökonomik und politischer Transformationsforschung. INEFReport 99/2009. Duisburg: Institut für Entwicklung und Frieden.

Priddat, Birger P., and Michael Schmid, eds. 2011. Korruption als Ordnung zweiter Art. Wiesbaden: VS Verlag für Sozialwissenschaften.

Rose-Ackerman, Susan. 1999. Corruption and Government. Causes, Consequences, and Reform. Cambridge: Cambridge University Press.

Sindzingre, Alice N., and Christian Milelli. 2010. The Uncertain Relationship Between Corruption and Growth in Developing Countries: Threshold Effects and State Effectiveness. EconomiX Working Papers 10. Nanterre: University of Paris West - Nanterre la Défense, EconomiX. 